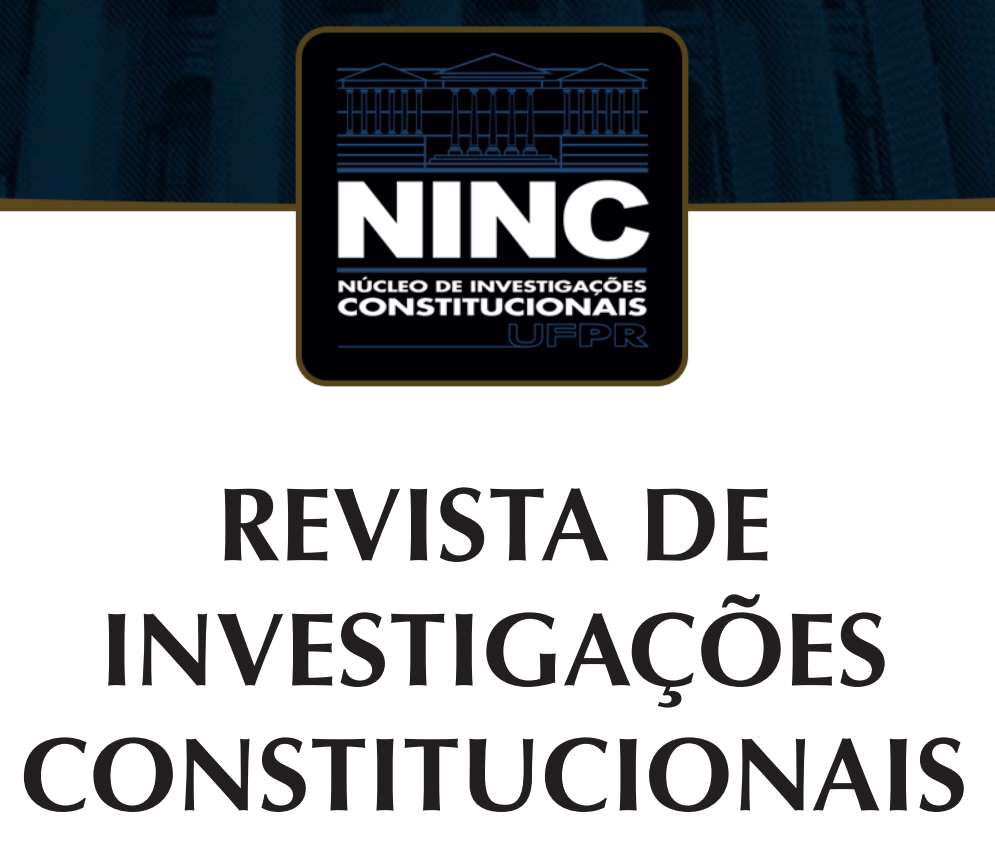

JOURNAL OF CONSTITUTIONAL RESEARCH

vol. 6 | n. 1 | janeiro/abril 2019 | ISSN 2359-5639 | Periodicidade quadrimestral Curitiba | Núcleo de Investigações Constitucionais da UFPR | www.ninc.com.br 


\title{
Sobre a noção de bem comum no pensamento político ocidental: entre becos e encruzilhadas da dimensão ancestral do moderno conceito de interesse público
}

\section{On the notion of the common good in the Western political thought: between alleys and crossroads of the ancestral dimension of the modern concept of public interest}

\author{
JOSÉ SERGIO DA SILVA CRISTOVAM ${ }^{\mathrm{I}, *}$ \\ ${ }^{\mathrm{I}}$ Universidade Federal de Santa Catarina (Brasil) \\ jscristovam@gmail.com \\ Recebido/Received: 21.01.2018 / January 21 $1^{\text {st }}, 2018$ \\ Aprovado/Approved: 29.04.2019 / April 29"th', 2019
}

Resumo

O artigo tem por objetivo discutir as bases da noção de bem comum no pensamento político ocidental, a partir da breve recuperação de algumas ideias centrais do pensamento político da Antiguidade clássica grega (Platão e Aristóteles) e romana (Marco Túlio Cícero), passando pela filosofia cristã da Idade Média (Santo Agostinho e Santo Tomás de Aquino), até as portas do pensamento político moderno (a moralidade política em Nicolau Maquiavel e o conceito de vontade geral em Jean-Jacques Rousseau). Assim, pretende-se estabelecer uma espécie de genealogia da noção de bem comum e em certa medida um
Abstract

The article aims at to discuss the bases of the notion of common good in Western political thought, from the short recovery of some central ideas of political thought from classical Greek antiquity (Plato and Aristotle) and Roman (Marco Tulio Cicero), to christian philosophy from the Middle Ages (St. Augustine and St. Thomas Aquinas), until the doors of modern political thought (the political morality in Niccolo Machiavelli and the concept of general desire in Jean-Jacques Rousseau). Thus, it is intended to establish a kind of genealogy of the notion of common good and dialogue with the modern dimension of public interest. The method and

Como citar esse artigo/How to cite this article: CRISTÓVAM, José Sergio da Silva. Sobre a noção de bem comum no pensamento político ocidental: entre becos e encruzilhadas da dimensão ancestral do moderno conceito de interesse público. Revista de Investigações Constitucionais, Curitiba, vol. 6, n. 1, p. 107-134, jan./abr. 2019. DOI: 10.5380/rinc.v6i1.57508.

"Professor Adjunto de Direito Administrativo no Curso de Graduação em Direito e no Programa de Mestrado em Direito do PPGD/UFSC (Florianópolis-SC, Brasil). Doutor em Direito Administrativo pela UFSC (Florianópolis-SC, Brasil) (2014), com estágio de Doutoramento Sanduíche junto à Universidade de Lisboa (Lisboa, Portugal) (2012). Mestre em Direito Constitucional pela UFSC (Florianópolis-SC, Brasil) (2005). Especialista em Direito Administrativo pelo CESUSC (2003). Membro fundador e Presidente do Instituto Catarinense de Direito Público (ICDP). Membro fundador do Instituto de Direito Administrativo de Santa Catarina (IDASC) e da Academia Catarinense de Direito Eleitoral (ACADE). Membro efetivo do Instituto dos Advogados de Santa Catarina (IASC). Conselheiro Estadual da OAB/SC. Presidente da Comissão de Acesso à Justiça da OAB/SC. Membro da Comissão de Direito Constitucional e da Comissão da Moralidade Pública da OAB/SC. Coordenador do Grupo de Estudos em Direito Público do CCJ/ UFSC (GEDIP/CCJ/UFSC). E-mail: jscristovam@gmail.com 
diálogo com a própria dimensão moderna de interesse público. O método utilizado é o dedutivo e monográfico e a técnica de pesquisa bibliográfica. technique used are, respectively, the deductive and monographic, and the bibliographic research.
Palavras-chave: bem comum; pensamento político ocidental; moralidade política; vontade geral; interesse público.
Keywords: common good; Western political thought; political morality; general desire; public interest.

\section{SUMÁRIO}

1. Introdução; 2. A construção da ideia de bem comum na Antiguidade clássica: Platão, Aristóteles e Cícero; 3. O bem comum na filosofia cristã da Idade Média: Santo Agostinho e Santo Tomás de Aquino; 4. A reconstrução da noção de bem comum no pensamento político moderno: a moralidade política em Maquiavel e o conceito de vontade geral em Rousseau; 5. Considerações Finais; 6. Referências.

\section{INTRODUÇÃO}

O presente ensaio pretende abordar a noção de bem comum no pensamento político ocidental, a partir da breve recuperação de algumas ideias centrais do pensamento político da Antiguidade clássica grega (Platão e Aristóteles) e romana (Marco Túlio Cícero), passando pela filosofia cristã da Idade Média (Santo Agostinho e Santo Tomás de Aquino), até as portas do pensamento político moderno (a moralidade política em Nicolau Maquiavel e o conceito de vontade geral em Jean-Jacques Rousseau). Com isso, o intuito é estabelecer uma espécie de genealogia do bem comum e até certo ponto um diálogo com a própria dimensão moderna do conceito do interesse público, subjacente ao debate entre interesses da coletividade (comunidade política) e a noção de direitos fundamentais individuais.

O debate se justifica, na medida em que a atual ordem constitucional brasileira, inaugurada com o advento da aclamada "Constituição Cidadã", veio a lume em meio a uma atmosfera festiva e cercada de alvissareira esperança democrática. É certo, porém, que, embora vencidas as suas três primeiras décadas e, por assim dizer, atingida a "maioridade civil" da (ainda política e socialmente infante) "abertura democrática brasileira", há ainda um considerável déficit de concretização de várias das promessas constitucionais. ${ }^{1}$ Nossa Constituição, multicolorida pela vivificadora e extensa aquarela de direitos sociais constitucionalizados, começa por dar sinais de fenecimento (ou, quem sabe, somente momentânea saturação), dada a (ainda) rarefeita concretização de algumas das suas promessas emancipatórias, libertárias e de igualdade social.

Na mesma esteira, resta inegável a profunda virada jurídico-metodológica operada a partir da Constituição de 1988, com o estabelecimento de uma prodigiosa carta

\footnotetext{
${ }^{1}$ SALGADO, Eneida Desiree. Essay on the constitutional promises of democracy and republic. Revista de Inves-
} tigações Constitucionais, Curitiba, vol. 4, n. 3. p. 85-100, set./dez. 2017. 
de direitos fundamentais, que erigiu a dignidade da pessoa humana à condição de fundamento da República Federativa do Brasil (artigo 1이이 da CF/88), procedendo a um insofismável deslocamento do epicentro da ordem normativa constitucional das competências e da estruturação dos poderes do Estado para a pessoa humana. ${ }^{2}$

Todo esse movimento de "personalização da ordem constitucional" traz consigo o debate em torno da relação entre interesses da coletividade, a partir de uma mais ou menos densa dimensão de supremacia do interesse público, e os direitos e interesses dos indivíduos (privados). Envolto nesses formidáveis ventos de constitucionalização, ${ }^{3}$ oportuno que se estabeleçam os contornos de uma ideia que é chave para a dimensão moderna de interesse público, ${ }^{4}$ a partir da recuperação da noção de bem comum no pensamento político ocidental, vasculhando seus becos e até, por vezes, enfrentando criticamente suas encruzilhadas, problema central desse ensaio, provocativamente sugerido desde o seu subtítulo.

Cumpre ressaltar que a recuperação aqui proposta não tem qualquer pretensão de oferecer uma análise crítica aprofundada e muito menos exauriente, com a recuperação desse relevante debate no âmbito da sociologia, da economia e até no contemporâneo diálogo em torno das questões ambientais (água, clima, patrimônio ambiental geral). ${ }^{5}$ O objetivo é repassar por alguns dos elementos filosóficos da noção de bem comum no pensamento político ocidental, ${ }^{6}$ desde a Antiguidade clássica até o adven-

\footnotetext{
${ }^{2}$ MEZZAROBA, Orides; SILVEIRA, Vladmir Oliveira da. The principle of the dignity of human person: A reading of the effectiveness of citizenship and human rights through the challenges put forward by globalization. Revista de Investigações Constitucionais, Curitiba, vol. 5, n. 1, p. 273-293, jan./abr. 2018.

${ }^{3}$ Para uma análise panorâmica do movimento de "constitucionalização do Direito", no modelo do Estado constitucional de direito, consultar: BARROSO, Luís Roberto. Neoconstitucionalismo e constitucionalização do direito: o triunfo tardio do direito constitucional no Brasil. Boletim da Faculdade de Direito da Universidade de Coimbra, Coimbra, ano 81, p. 233-289, 2005.

${ }^{4}$ Nesse sentido, oportunas as considerações de Maria Sylvia Zanella Di Pietro sobre a recuperação da noção de interesse público a partir da ideia de bem comum construída desde a Antiguidade clássica: "Embora possa parecer que o princípio da supremacia do interesse público tenha sido criado no âmbito do direito administrativo, na verdade ele antecede em muitos séculos o nascimento desse ramo do direito, que somente começou a se formar como ramo autônomo em fins do século XVIII, com a formação do Estado de Direito. De fato, a ideia de existência de interesses gerais diversos dos interesses individuais encontra suas origens na antiguidade greco-romana". DI PIETRO, Maria Sylvia Zanella. O princípio da supremacia do interesse público: sobrevivência diante dos ideais do neoliberalismo. In: DI PIETRO, Maria Sylvia Zanella; RIBEIRO, Carlos Vinícius Alves (Coord.). Supremacia do interesse público e outros temas relevantes do direito administrativo. São Paulo: Atlas, 2010. p. 86.

${ }^{5}$ Para uma análise dessa temática, com o debate no âmbito da comunidade europeia, consultar: PATO, João; SCHMIDT, Luísa; GONÇALVES, Maria Eduarda (Org.). Bem comum: público e/ou privado. Lisboa: ICS (Imprensa de Ciências Sociais), 2013. Disponível em: <http://repositorio.ul.pt/bitstream/10451/22896/1/ICS_JPato_LSchmidt_LEN.pdf>. Acesso em 21 jan. 2018.

${ }^{6}$ Para um debate crítico e atual sobre a relação entre a ideia de crise e a dimensão do bem comum da humanidade, consultar: HOUTART, François. Dos bens comuns ao “bem comum da humanidade”. Bruxelas: Rosa Luxemburg Foundation Brussels Office, 2011. Disponível em: <http://www.reformaagrariaemdados.org. br/sites/default/files/Dos\%20bens\%20comuns\%20ao\%20Bem\%20Comum\%20da\%20Humanidade\%20-\%20 Fran\%C3\%A7ois\%20Houtart\%202011.pdf>. Acesso em 21 jan. 2018.
} 
to do pensamento moderno, com vistas a oferecer as bases sobre as quais se podem assentar modernas instituições jurídico-políticas como o interesse público e em certa medida a própria noção de direitos fundamentais. ${ }^{7}$

Com efeito, a noção de interesse público ${ }^{8}$ não pode ser estruturada, de forma atropelada e descontextualizada, a partir do nascimento do Estado liberal de direito e no palco instaurado pela histórica Revolução Francesa, embora tenha sido nesse efervescente e singular momento que se tenham forjado os seus contornos comuns ao Estado moderno que engatinhava, juntamente com o advento do próprio Direito Administrativo como ramo autônomo do Direito. ${ }^{9}$

O início da genealogia proposta recupera as bases da reflexão política na Antiguidade clássica, a partir da ideia de "bem comum"10 - aqui debatida como raiz política ancestral e núcleo originário do moderno conceito jurídico de interesse público.

\section{A CONSTRUÇÃO DA IDEIA DE BEM COMUM NA ANTIGUIDADE CLÁSSICA: PLATÃO, ARISTÓTELES E CÍCERO}

O pensamento político que floresceu na Grécia antiga, sobretudo na Atenas dos séculos VI a IV a.C., teve como substrato propulsor a canalização de todo o resplendor da filosofia, da ciência e da cultura para o campo específico do conhecimento e da

\footnotetext{
${ }^{7}$ Para uma abalizada leitura sobre a relação entre a noção de bem comum constitucional e os direitos fundamentais, consultar: MEZZAROBA, Orides; STRAPAZZON, Carlos Luiz. Direitos fundamentais e a dogmática do bem comum constitucional. Revista Sequência: Estudos Jurídicos e Políticos, Florianópolis, v. 33, n. 64, p. 335-372, jul. 2012. Disponível em: <https://periodicos.ufsc.br/index.php/sequencia/article/view/2177-7055. 2012v33n64p335/22475>. Acesso em 21 jan. 2018.

${ }^{8}$ Sobre o rico debate em torno da noção de interesse público e suas nuances, consultar: CRISTÓVAM, José Sérgio da Silva. Administração Pública democrática e supremacia do interesse público: novo regime jurídico-administrativo e seus princípios constitucionais estruturantes. Curitiba: Juruá, 2015; GABARDO, Emerson. Interesse público e subsidiariedade: o Estado e a sociedade civil para além do bem e do mal. Belo Horizonte: Fórum, 2009; GABARDO, Emerson. O princípio da supremacia do interesse público sobre o interesse privado como fundamento do Direito Administrativo Social. Revista de Investigações Constitucionais, Curitiba, vol. 4, n. 2, p. 95-130, maio/ago. 2017; HACHEM, Daniel Wunder. Princípio constitucional da supremacia do interesse público. Belo Horizonte: Fórum, 2011; HAEBERLIN, Mártin Perius. Crítica da razão do Estado: uma (re) formulação do conceito de interesse público e a correlata construção de um Estado meritocrático de direito. 2014. 454 f. Tese (Doutorado de Direito) - Faculdade de Direito da Pontifícia Universidade Católica do Rio Grande do Sul, Porto Alegre, 2014.

${ }^{9}$ RODRÍGUEZ-ARANA MUÑOZ, Jaime. El Derecho Administrativo ante la crisis (El Derecho Administrativo Social). A\&C - Revista de Direito Administrativo \& Constitucional, Belo Horizonte, ano 15, n. 60, p. 13-37, abr./ jun. 2015.

${ }^{10}$ Como já adiantado, a análise da categoria "bem comum" aqui se restringe, mais especificamente, aos seus contornos afetos à teoria e à filosofia política, passando em rápida revista por algumas das suas nuances filosóficas, quando relacionada àquele plano. Refoge aos contornos desse estudo o debate (riquíssimo por sinal) da noção de bem comum no âmbito da ética, da sociologia, da antropologia e da economia, por exemplo. Para uma análise do bem comum na economia, pode-se consultar: BRUNI, Luigino. Bem comum e economia: para uma economia baseada no ágape. Tradução de Luís Miguel Neto. Instituto Superior de Ciências Sociais e Políticas (ISCSP). Universidade Técnica de Lisboa (UTL), Lisboa, p. 01-11, 2008. Disponível em: <http://www. academia.edu/2576914/Bem_Comum_e_Economia_Para_uma_Economia_baseada_no_Agape_-_trad._do_ original_de_Luigino_Bruno>. Acesso em: 17 jan. 2018.
} 
ação - a política. Conforme ressalta Ivone Morcilo Lixa, era a convivência na pólis que constituía o grego da Antiguidade clássica como "cidadão e conferia-lhe uma condição de vida digna. Não se tratava apenas de viver num aglomerado urbano, mas, sobretudo, de ser parte integrante de uma unidade política e social organizada, limitada territorialmente".11

Para o homem grego, a convivência plural na pólis dotava de sentido e individualidade a própria existência humana, verdadeiro pressuposto da sua identidade individual e política, o que o diferenciava (na qualidade de cidadão grego) daqueles que não eram assim qualificados, a partir do exercício da liberdade, precondição determinante para a existência de uma vida digna. Sobre a centralidade da ideia de liberdade e sua exclusividade ao cidadão grego (aquele que vive a ação política), Hannah Arendt afirma que dentre todas as atividades humanas que poderiam assegurar ao homem uma condição de vida digna e verdadeiramente humana, a vida política e a dedicação aos assuntos da pólis ocupava lugar especialmente destacado. ${ }^{12}$

Conquanto seja inegável a existência de uma noção embrionária de pólis anterior à Atenas dos séculos VI a IV a.C., em que se forjaram as bases do pensamento político clássico, foi justamente nesse período que floresceram os fundamentos da reflexão política legada ao Ocidente. Para o cidadão grego, a vida na pólis estava dividida em duas esferas: a privada, relacionada em especial ao patrimônio, ao casamento e à família, sob a representação da "casa" (oíkos - síntese da vida privada); e a pública, onde o cidadão grego debatia as questões políticas e as instituições sobre as quais se fundava a pólis. Afora a existência individual do homem grego (vida privada), havia esta segunda dimensão existencial, na qual o homem poderia realizar as suas virtudes de convivência política (dimensão pública ou comum), o que o qualificava como efetivo cidadão da pólis. ${ }^{13}$

Nesse contexto, coube à filosofia platônica o estabelecimento dos alicerces da política como ciência ("ciência política"), sob o princípio de que somente uma forma política fundamentada no saber filosófico poderia conduzir à verdadeira justiça. Herdeiro do pensamento pitagórico ${ }^{14}$ e socrático, ${ }^{15}$ Platão (Aristocles, 428/427 - 348/347 a.C.) entendia a justiça como uma virtude universal que engloba sabedoria, fortaleza e

${ }^{11}$ LIXA, Ivone Morcilo. O sentido da política em Platão e Aristóteles. In: WOLKMER, Antonio Carlos (Org.). Introdução à história do pensamento político. Rio de Janeiro: Renovar, 2003. p. 14.

${ }^{12}$ ARENDT, Hannah. A condição humana. Tradução de Celso Lafer. Rio de Janeiro: Forense, 1983. p. 16-21.

${ }^{13}$ LIXA, Ivone Morcilo. O sentido da política em Platão e Aristóteles. In: WOLKMER, Antonio Carlos (Org.). Introdução à história do pensamento político. Rio de Janeiro: Renovar, 2003. p. 16.

${ }^{14}$ Sobre o tema, consultar: SZLEZÁK, Thomas Alexander. Platão e os pitagóricos. Tradução de Fernando Augusto da Rocha Rodrigues. Archai: Revista de Estudos sobre as Origens do Pensamento Ocidental. Brasília, n. 6, p. 121-132, 2011.

${ }^{15}$ CHEVALLIER, Jean-Jacques. História do pensamento político. v. 1. Tradução de Roberto Cortes de Lacerda. Rio de Janeiro: Zahar, 1982. p. 47-50. 
prudência (phrónesis), na medida em que dependem da sua existência, pelo que apenas com tal coexistência seria possível a harmonia social. Somente a sabedoria filosófica (sophía) seria capaz de proporcionar o equilíbrio da pólis, pelo que a prudência (ciência subordinada à sabedoria) estaria relacionada ao bom governo fundado nas "Ideias do Bem" e na justiça.

Interessante ressaltar que, para a filosofia platônica, a grande meta (maior lição) a guiar a condição humana "não é senão a ideia do Bem, isto é, aquilo em virtude de que tudo o que é justo, belo, etc., é proveitoso e salutar. Sem o conhecimento dela, qualquer outro saber seria inútil".16

Para o pensamento platônico, a educação, a moral e a política são os esteios do "Bem Comum", ${ }^{17}$ pelo que a original ciência política ("ciência do Bem") seria o fundamento da Cidade ideal - uma cidade governada por filósofos (rei-filósofo) e racionalmente hierarquizada em classes homogêneas (chefes de governo, auxiliares ou guerreiros e artífices ou camponeses). A justiça consistiria na ideia que determina a cada um o respeito à hierarquia social e política, do que decorreria a estabilidade social, na medida em que todos seriam capazes de entender as renúncias pessoais e egoísticas impostas pela razão, controlando as suas paixões individuais em favor do equilíbrio da totalidade social. ${ }^{18}$

Na República, a noção de "Bem" como "Ideia" é apresentada por Platão com especial centralidade, verdadeiro "princípio supremo da filosofia platônica", 19 "a norma absoluta que serve de base à noção da filosofia como suprema 'arte da medida', a qual aparece desde muito cedo no pensamento platônico e nele se mantém até o final".20 O filósofo explica a "Ideia de bem" a partir de uma metáfora da função reveladora da luz e do sol sobre as coisas sensíveis e da relação do conhecimento e da verdade e sua relação com o bem, como uma forma ideal perfeita do mundo inteligível (Forma/ldeia do bem), que concede verdade às coisas conhecidas e o poder de conhecê-las. Após relembrar as virtudes da justiça, da moderação, da coragem e da sabedoria, o filósofo

\footnotetext{
${ }^{16}$ JAEGER, Werner. Paidéia: a formação do homem grego. Tradução de Artur M. Parreira. São Paulo: Martins Fontes, 2011. p. 867.

${ }_{17}^{17}$ TEIXEIRA, Evilázio. A educação do Homem segundo Platão. São Paulo: Paulus, 1999. p. 15-18.

${ }^{18} \mathrm{As}$ bases do pensamento platônico acerca da Cidade ideal e da ideia de bem comum podem ser recuperadas dos Livros V, VI e VII da República, uma noção de bem como Ideia universal construída a partir de um modelo de vida terrena que remetia inexoravelmente a princípios metafísicos - modelo idealista de reflexão filosófica fundado nos chamados "primeiros princípios", desgarrado do mundo sensível e de complexo entendimento até para os filósofos. Nesse sentido, consultar: PLATÃO. A República. Tradução de Edson Bini. 2. ed. São Paulo: EDIPRO, 2012. p. 203-325.

19 JAEGER, Werner. Paidéia: a formação do homem grego. Tradução de Artur M. Parreira. São Paulo: Martins Fontes, 2011. p. 870.

${ }^{20}$ JAEGER, Werner. Paidéia: a formação do homem grego. Tradução de Artur M. Parreira. São Paulo: Martins Fontes, 2011. p. 876.
} 
sustenta que "a coisa mais importante a ser apreendida é a Ideia de bem e que é mediante a referência a ela que coisas justas e as outras se tornam úteis e benéficas".21

A centralidade da educação (paidéia) na construção da filosofia de Platão e na sua "República" fica evidente, dentre outras passagens, na difundida "alegoria da caverna", quando o filósofo descreve homens que vivem presos (acorrentados) desde a infância em uma caverna subterrânea (mundo do visível), com uma longa galeria que se abre para a luz de uma grande fogueira, sendo que somente lhes é permitido olhar para frente, de costas para a saída. Os clarões da fogueira (o sol) iluminam sobre as cabeças dos prisioneiros até a parede a sua frente, projetando sombras de vários objetos e figuras, manobradas por manipuladores situados atrás de um muro baixo colocado entre os prisioneiros e a saída iluminada. Para os prisioneiros, que jamais puderam olhar para a saída da gruta, aquelas sombras projetadas na parede são a realidade. Mas e se um dos prisioneiros fosse posto em liberdade e pudesse enfim contemplar a luz? Certamente, em um primeiro momento teria uma enorme dificuldade de fitar a luz e toda a aquarela das coisas (verdadeiras e reais - Formas perfeitas e imutáveis do mundo inteligível), continuando a pensar que a realidade estaria no mundo das sombras (mundo do visível), devendo voltar para a caverna (ignorância). Mas depois passaria a acostumar sua visão (evolução), passando a contemplar todas as coisas, até se sentir capaz de olhar diretamente para o sol (mundo inteligível), o que simboliza a ascensão para o alto e a contemplação do mundo superior (caminho da alma em direção ao mundo inteligível pela via reveladora (conversão) da educação - paidéia). ${ }^{22}$ Para o idealismo platônico a "última coisa que na região do conhecimento puro a alma aprende a ver, 'com esforço', é a ideia do Bem", sendo que, "uma vez que aprende a vê-la, tem necessariamente de chegar à conclusão de que esta ideia é a causa de tudo o que no mundo existe de belo e de justo, e de que forçosamente deve tê-la contemplado que quiser agir racionalmente tanto na vida privado como na pública".23

Na filosofia platônica o "bem-comum é, assim, sempre, o bem máximo de cada ser humano, mas em integração sinfonial como o bem máximo, possível e real, de todos os outros, em acto, em cada instante", sendo esse o "fundamento metafísico da dimensão política da realidade humana. A política nasce da necessidade que cada indivíduo humano tem de bens que não pode, por si só, adquirir".24

\footnotetext{
${ }^{21}$ PLATÃO. A República. Tradução de Edson Bini. 2. ed. São Paulo: EDIPRO, 2012. p. 276-284.

${ }^{22}$ PLATÃO. A República. Tradução de Edson Bini. 2. ed. São Paulo: EDIPRO, 2012. p. 289-294.

${ }^{23}$ JAEGER, Werner. Paidéia: a formação do homem grego. Tradução de Artur M. Parreira. São Paulo: Martins Fontes, 2011. p. 885.

${ }^{24}$ PEREIRA, Américo. Da ontologia da "polis" em Platão. Covilhã: LusoSofia - Biblioteca Online de Filosofia e Cultura, p. 03-102, 2011. Disponível em: <http://pt.scribd.com/doc/56971910/Pereira-Americo-Ontologia-Da-Polis-Em-Platao>. Acesso em: 17 jan. 2018.
} 
A noção de bem comum a partir da convivência na pólis é recuperada e redimensionada por Aristóteles (384 - 322 a.C.). Já no primeiro parágrafo do Livro Primeiro da Política, o Filósofo de Estagira sustenta que "toda cidade é uma espécie de associação, e que toda associação se forma tendo por alvo algum bem; porque o homem só trabalha pelo que ele tem em conta de um bem", sendo que todas as "sociedades, pois, se propõem qualquer bem - sobretudo a mais importante delas, pois que visa a um bem maior, envolvendo todas as demais: a cidade ou sociedade política".25

Com efeito, na filosofia prática aristotélica ${ }^{26}$ a diferença entre o ser humano e outros animais está fundada na pólis (convivência política), vínculo natural e necessário dos homens (ordem imutável do mundo). A condição humana decorre da convivência na cidade (ação política), sendo "evidente, pois, que a cidade faz parte das coisas da natureza, que o homem é naturalmente um animal político, destinado a viver em sociedade, e que aquele que, por instinto, e não porque qualquer circunstância o inibe, deixa de fazer parte de uma cidade, é um ser vil ou superior ao homem".27

Assim, fundado no que se pode atualmente conceber como uma "metodologia científica", que esteve ausente na ciência política platônica, a partir do Livro IV da Política, o Filósofo de Estagira apresenta uma análise empírica das características e do funcionamento dos regimes políticos conhecidos na época, com vistas à descrição de um modelo ideal de governo, que tem um claro fim ético na qualidade de princípio político - "a crença na construção de um modo de vida digno e feliz". ${ }^{28}$

A teoria aristotélica formula a distinção dos governos em autênticos ou constitucionais e degenerados ou despóticos, com base na ideia central de "bem comum", comum aos governos constitucionais e estranha aos governos despóticos, que estariam voltados ao bem da classe dominante. Mas o conceito de bem comum em Aristóteles não pode ser entendido a partir de um modelo idealista ou universal (suprassensível), capaz de ser aprisionado em um princípio atemporal e metafísico. Sob a justificativa do caráter indeterminado do que se deve entender por "bem", tão plurissignificativo quanto a categoria do "ser" e suas infindáveis conotações, o Filósofo Estagirita afirmava ser "evidente que não há nenhum bem comum, universal e uno, porque, se assim fosse, não poderia ser predicado de todas aquelas diferentes categorias, mas teria que existir de acordo com uma única", pelo que "se para os objetos que são compreendidos a partir de uma determinada ideia há uma única perspectiva

\footnotetext{
${ }^{25}$ ARISTÓTELES. A Política. Tradução de Nestor Silveira Chaves. 2. ed. São Paulo: EDIPRO, 2009. p. 13.

${ }^{26} \mathrm{~A}$ título ilustrativo, convém ressaltar que a obra de Aristóteles divide a filosofia basicamente em três grandes ramos, que abrangeriam todo o saber humano (racional): a filosofia teorética, que se subdividia em física, matemática, metafísica e teologia; a filosofia prática, subdividida em ética e política; e a filosofia poética, formada pela estética e pela técnica.

${ }^{27}$ ARISTÓTELES. A Política. Tradução de Nestor Silveira Chaves. 2. ed. São Paulo: EDIPRO, 2009. p. 16.

${ }^{28} \mathrm{LIXA}$, Ivone Morcilo. O sentido da política em Platão e Aristóteles. In: WOLKMER, Antonio Carlos (Org.). Introdução à história do pensamento político. Rio de Janeiro: Renovar, 2003. p. 31.
} 
científica, assim também haveria uma única ciência para todas as formas de manifestação de bem". ${ }^{29}$

No Livro I da sua Ética a Nicômaco, Aristóteles apresenta a noção de felicidade ou bem-estar da alma (eudaimonía) como o bem supremo e universal do homem, o fim último de todas as ações possíveis. Por outro lado, embora reconheça a existência de um bem único, que seja um predicado universal dos bens, o filósofo procura redimensionar e superar a teoria platônica das Formas e da "Ideia de bem" (o Bem Supremo como algo suprassensível), a partir de um conceito de bem que seja possível aos homens atingir, os bens terrenos atingíveis por meio da ação política, ou seja, aqueles fins (bens) que se pretende atingir por meio de determinada prática (ação política no mundo sensível). ${ }^{30}$

De fato, a noção organicista aristotélica de bem comum não reflete um conceito individualista (particular/privado) de homem, não obstante defenda que os bens sejam finalidades atingíveis por cada um segundo os respectivos meios adequados. Pelo contrário, na filosofia prática aristotélica a prudência (phrónesis) ${ }^{31}$ funciona como "catalisador ético" para as ações individuais adequadas às virtudes morais (ação virtuosa), no sentido de que o bem de um deve ser o bem de todos (bem geral). Somente a convivência humana na pólis, por meio da ação política na esfera pública (comum ao cidadão grego), é o que permite o desenvolvimento moral do homem, a via por excelência para alcançar a sua plenitude e a felicidade (bem supremo).

A partir de comentários sobre a noção do primado do público, Norberto Bobbio recupera a clássica doutrina aristotélica sintetizada no princípio segundo o qual "o todo vem antes das partes", o que permitiria afirmar que "a totalidade tem fins não reduzíveis à soma dos fins dos membros singulares que a compõem e o bem da totalidade, uma vez alcançado, transforma-se no bem das suas partes". Portanto, "o máximo bem dos sujeitos é o efeito não da perseguição, através do esforço pessoal e do antagonismo, do próprio bem por parte de cada um, mas da contribuição que cada um juntamente com os demais dá solidariamente ao bem comum",32 conforme as regras adotadas pela comunidade toda.

\footnotetext{
${ }^{29}$ ARISTÓTELES. Ética a Nicômaco. Tradução de António de Castro Caeiro. São Paulo: Atlas, 2009. p. 23.

${ }^{30}$ ARISTÓTELES. Ética a Nicômaco. Tradução de António de Castro Caeiro. São Paulo: Atlas, 2009. p. 22-39.

${ }^{31} \mathrm{~A}$ "prudência" (phrónesis), uma das virtudes máximas e categoria central na filosofia prática aristotélica, assegura ao homem a disposição para a ação política por meio de práticas adequadas aos fins que se pretende alcançar, virtude que seria comum à classe média (princípio aristotélico da moderação). A prudência não deve ser entendida como conhecimento científico, mas como uma disposição da alma racional (virtude intelectual), relacionada com aquilo que é justo, destinada à ação política do homem no mundo da vida. Na ética aristotélica, a prudência é a qualidade racional que conduz à verdade no que toca às ações relacionadas como os bens humanos. ARISTÓTELES. Ética a Nicômaco. Tradução de António de Castro Caeiro. São Paulo: Atlas, 2009. p. 01-14.

${ }^{32} \mathrm{BOBBIO}$, Norberto. Estado, governo, sociedade: para uma teoria geral da política. Tradução de Marco Aurélio Nogueira. 14. ed. Rio de Janeiro: Paz e Terra, 2007. p. 24-25.
} 
Essa é a noção-chave do conceito aristotélico de bem comum: a convivência humana na pólis, garantidora do desenvolvimento moral do cidadão e estrada que conduz o homem ao bem supremo da felicidade (noção de vida boa), por meio da virtuosa ação política na esfera pública.

Para a filosofia política de Aristóteles esta seria, inclusive, a finalidade principal e o próprio sentido da existência do Estado (Cidade), uma forma de organização política inerente à condição humana (natural) e que propicia o mais elevado desenvolvimento moral do cidadão, condição para a plena felicidade do homem. ${ }^{33}$ Nas palavras do filósofo, "o Estado está na ordem da natureza e antes do indivíduo; porque, se cada indivíduo isolado não se basta a si mesmo, assim também se dará com as partes em relação ao todo", o que permite concluir que "aquele que não pode viver em sociedade, ou que de nada precisa por bastar-se a si próprio, não faz parte do Estado; é um bruto ou um deus".34

O "indivíduo aristotélico" não é um ser isolado (particular). Está necessariamente vinculado aos outros homens, na busca e na realização dos seus próprios bens, porquanto somente a organização comunitária na cidade (esfera pública) permitiria a realização plena da vida racional legada ao homem pela própria natureza das coisas. O homem, individualmente, jamais poderá bastar-se a si mesmo (ideia de autarquia) e atingir sua finalidade suprema (felicidade). Isso somente poderá ser alcançado por meio da ação política virtuosa na cidade (a autarquia do cidadão). Eis o conceito aristotélico de bem comum, a medida da felicidade na qualidade de bem supremo, atingível por meio da ação política virtuosa (prudência), restando indissociáveis a felicidade individual e a coletiva, já que ao homem somente é dado alcançar a plenitude e a suprema felicidade pela senda da vida política virtuosa (esfera pública).

Ainda que de inegável sofisticação, se transportado para a atualidade, não há como negar o componente autoritário e antidemocrático do pensamento aristotélico de bem comum, vez que fundado em uma perspectiva claramente organicista, no sentido de que o interesse da coletividade deve preponderar sobre as aspirações particulares de cada indivíduo. Um conceito de bem comum que submete as aspirações e interesses da pessoa aos desígnios da coletividade acaba por sufocar e até suplantar uma noção personalista de dignidade humana muito presente nos modelos de Estado constitucional de direito posteriores à Segunda Guerra Mundial. Há uma série de direitos e interesses individuais, inerentes e constitutivos de uma dimensão personalista da

\footnotetext{
${ }^{33}$ Ultrapassam os limites da presente abordagem a recuperação filosófica, política, sociológica ou até psicológica do conceito de felicidade. Para estudos sobre o tema, consultar: WHITE, Nicholas. Breve história da felicidade. Tradução de Luis Carlos Borges. São Paulo: Loyola, 2009; SEWAYBRICKER, Luciano Espósito. A felicidade na sociedade contemporânea: contraste entre diferentes perspectivas filosóficas e a Modernidade líquida. 2012. 159 f. Dissertação (Mestrado em Psicologia) - Instituto de Psicologia da Universidade de São Paulo, São Paulo, 2012.

${ }^{34}$ ARISTÓTELES. A Política. Tradução de Nestor Silveira Chaves. 2. ed. São Paulo: EDIPRO, 2009. p. 17.
} 
dignidade humana, que não podem estar submetidos a uma lógica de compatibilidade ou não aos cambiantes interesses da coletividade. ${ }^{35}$

Uma análise mais detida do modelo organicista, de matriz aristotélica, acaba por demonstrar uma considerável dose de desprestígio à pessoa humana e ao seu valor intrínseco na qualidade de indivíduo, independentemente do seu papel social ou da sua função na comunidade política. Cada pessoa traz em si um conjunto de interesses e valores próprios (dimensão privada do indivíduo), incapazes de serem adequada e integralmente reconduzidos a uma ideia totalizante de entidade coletiva (dimensão pública).

No mesmo quadrante, a ideia de que cada indivíduo somente encontra sua felicidade (bem supremo) quando passa a integrar a comunidade política e nela desempenhar a sua respectiva função, contribuindo para o bem comum geral, traz em si (em potência) a genética de uma sociedade estática, organizada por castas (avessa ou, pelo menos, pouco preocupada com a questão da mobilidade social), onde cada indivíduo já nasceria com uma determinada função na comunidade. Um modelo de sociedade assim delineado e uma noção de bem comum capaz de tolher, ainda que indiretamente, a dinâmica e dialética condição e posição social do indivíduo, parece inconciliável com a ideia de dignidade humana construída a partir da Modernidade e com a própria ordem constitucional brasileira.

Sem embargo da prodigiosa feição político-filosófica de bem comum na Grécia antiga, da Antiguidade clássica romana também é possível colher uma aprimorada abordagem, de caráter mais jurídico-político, a partir da dicotômica definição do Direito Público (jus publicum) e do Direito Privado (jus privatum) legada ao Ocidente. Nesta seara, inicialmente releva considerar que, tanto nas Institutiones (I.1.4) como no Digesto (I.1.1.2), a divisão Direito Público/Direito Privado é referida com idênticas palavras: o Direito Público diz respeito ao estado da coisa romana, o privado à utilidade dos particulares (publicum jus est quod ad statum rei romanae spectat, privatum, quod ad singulorum utilitatem).

Com efeito, essa noção embrionária polarizadora da relação público/privado já se fundava na centralidade de uma ideia jurídico-política de interesse: se vinculada aos interesses do Estado, atraia as normas comuns ao Direito Público; se relacionada aos interesses dos indivíduos, impunha as normas de Direito Privado. Mesmo assim, reconhecia-se "algum poder jurídico (ius) do povo, diverso do direito dos indivíduos", o que pode ser recuperado a partir do seguinte brocardo: "Assim o povo romano usa, em

\footnotetext{
${ }^{35}$ Sobre o tema, consultar: CRISTÓVAM, José Sérgio da Silva. Administração Pública democrática e supremacia do interesse público: novo regime jurídico-administrativo e seus princípios constitucionais estruturantes. Curitiba: Juruá, 2015. p. 185-215; SARMENTO, Daniel. Interesses públicos vs. Interesses privados na perspectiva da teoria e da filosofia constitucional. In: SARMENTO, Daniel. Interesses públicos versus interesses privados: desconstruindo o princípio da supremacia do interesse público. Rio de Janeiro: Lumen Juris, 2005, p. 23-116.
} 
parte, de seu direito próprio e, em parte, do comum a todos os homens" (Populus itaque Romanus partim suo proprio, partim communi omnium hominum jure utitur). ${ }^{36}$

A centralidade da dicotomia público/privado é destacada e recuperada por Bobbio, quando a qualifica como "uma daquelas 'grandes dicotomias', das quais uma ou mais disciplinas, neste caso não apenas as disciplinas jurídicas, mas também as sociais e em geral históricas, servem-se para delimitar, representar, ordenar o próprio campo de investigação", como ocorre, por exemplo, "para ficar no âmbito das ciências sociais, paz/guerra, democracia/autocracia, sociedade/comunidade, estado de natureza/estado civil".37

Conquanto não seja possível afiançar a existência de uma divisão de intransponíveis contornos, havendo sim espaços cinzentos ou de justaposição entre essas esferas jurídicas, ${ }^{38}$ na evolução do Direito Romano é destacada a distinção que os seus jurisconsultos faziam entre as relações jurídicas de Direito Público, que diziam respeito à organização do Estado romano e às coisas úteis à vida pública, e aquelas de Direito Privado, relacionadas ao bem de cada um e à vida privada. Desta forma, os interesses privados eram identificados como os interesses dos particulares, ao passo que os interesses públicos restavam relacionados e atribuídos às coisas do Estado e do povo romano (condomínio de interesses). Inclusive, uma das notas características do Estado romano era a "plena unidade da noção de poder público, como o imperium em que se baseia o direito público".39

Nesse sentido, pode-se recuperar na obra de Cícero (106 - 43 a.C.) a importante noção de utilidade comum (utilitas communis), quando sustenta no parágrafo XXV do Livro I do seu Da República que a justificativa para a organização dos homens em sociedade é menos uma questão de debilidade e mais um instinto inato de sociabilidade, sendo correto afirmar que a espécie humana não nasceu para o isolamento e para a vida errante, "mas com uma disposição que, mesmo na abundância de todos os bens, a

\footnotetext{
${ }^{36}$ CARVALHO FILHO, José dos Santos. Interesse público: verdades e sofismas. In: DI PIETRO, Maria Sylvia Zanella; RIBEIRO, Carlos Vinícius Alves (Coord.). Supremacia do interesse público e outros temas relevantes do direito administrativo. São Paulo: Atlas, 2010. p. 69.

${ }^{37} \mathrm{BOBBIO}$, Norberto. Estado, governo, sociedade: para uma teoria geral da política. Tradução de Marco Aurélio Nogueira. 14. ed. Rio de Janeiro: Paz e Terra, 2007. p. 13.

${ }^{38}$ Inegavelmente, o Direito Romano consolidou-se a partir da divisão nas esferas do Direito Público e do Direito Privado, sob o signo divisor do interesse (conteúdo da relação jurídico-política), cabendo ao Direito Público aquelas relações em que o Estado (povo) romano tomava parte, e ao Direito Privado aquelas travadas entre os indivíduos e seus interesses particulares. Por outro lado, havia situações em que o Estado intervinha diretamente em atos jurídicos de ordem privada, deixando também para a órbita do Direito Privado situações que envolviam matérias de ordem pública e de interesse geral. Nesse sentido: NEQUETE, Eunice Ferreira. Fundamentos históricos do princípio da supremacia do interesse público. 2005. 238 f. Dissertação (Mestrado em Direito) - Faculdade de Direito da Universidade Federal do Rio Grande do Sul, Porto Alegre, 2005. p. 23-28.

${ }^{39}$ NEQUETE, Eunice Ferreira. Fundamentos históricos do princípio da supremacia do interesse público. 2005. 238 f. Dissertação (Mestrado em Direito) - Faculdade de Direito da Universidade Federal do Rio Grande do Sul, Porto Alegre, 2005. p. 13-14.
} 
leva a procurar o apoio comum", pelo que seria "a República coisa do povo, considerando tal, não todos os homens de qualquer modo congregados, mas a reunião que tem seu fundamento no consentimento jurídico e na utilidade comum".40

Por outro lado, Eunice Ferreira Nequete adverte que, embora Cícero tivesse afirmado que traria um grande problema para a coletividade quem fizesse prevalecer seu interesse exclusivo e egoísta, com o enredo do interesse privado ou utilidade privada sob os limites da "honestidade", o Filósofo Romano não o teria confrontado ao interesse do Estado romano. Em Cícero, a utilidade comum (interesse público) não estaria ligada à noção de honestidade, mas ao que se pode entender pelo "espírito romano", de forma que não poderia ser resumida a uma estreita utilidade política vinculada e limitada aos fins mesquinhos da "razão de Estado". Desta maneira, "não haveria como o interesse privado ser outro que não coincidente com o interesse comum, mas se alguma oposição 'aparente' surgisse entre ambos este último deveria prevalecer".41

Em síntese, pode-se notar que a noção romana de utilidade pública, que deveria prevalecer sobre as aspirações privadas e egoísticas do indivíduo, traz em si um aspecto republicano de espaço público e de propriedade coletiva de bens e interesses (coisa pública), totalmente diversa daquela conhecida pela Modernidade. A perspectiva de propriedade coletiva de determinados bens e interesses, a partir da disposição política da República romana, estava fundada em uma clara ideia de efetiva participação do povo na formação das decisões sobre as questões de utilidade pública (interesse público), em um colorido muito diferente daquela dimensão estatal autoritária e monopolista agravada com a construção do Estado moderno. ${ }^{42}$

\section{O BEM COMUM NA FILOSOFIA CRISTÃ DA IDADE MÉDIA: SAN- TO AGOSTINHO E SANTO TOMÁS DE AQUINO}

Toda a construção política e jurídica da Antiguidade clássica grega e romana reverberou pelos séculos que sucederam, influenciando sobremaneira a Idade Média e o próprio Direito Canônico do Medievo. Aqui, para a recuperação das noções de "bem comum", assume invulgar relevo o pensamento político dos chamados períodos da $\mathrm{Pa}$ trística e da Escolástica. ${ }^{43}$

\footnotetext{
${ }^{40}$ CÍCERO, Marco Túlio. Da República. Tradução de Amador Cisneiros. Bauru: EDIPRO, 1995. p. 23.

${ }^{41}$ NEQUETE, Eunice Ferreira. Fundamentos históricos do princípio da supremacia do interesse público. 2005. 238 f. Dissertação (Mestrado em Direito) - Faculdade de Direito da Universidade Federal do Rio Grande do Sul, Porto Alegre, 2005. p. 15-16.

${ }^{42}$ Sobre o tema, consultar: CRISTÓVAM, José Sérgio da Silva. Administração Pública democrática e supremacia do interesse público: novo regime jurídico-administrativo e seus princípios constitucionais estruturantes. Curitiba: Juruá, 2015. p. 310-325.

${ }^{43} \mathrm{O}$ pensamento político na Alta Idade Média teve como destacada fase representativa de seus fundamentos filosóficos o período da chamada Patrística (séculos II até VI d.C.), em que os “Padres Apologistas, conhecedores do pensamento antigo, mas voltados para um modo santo de viver, uma postura intelectual ortodoxa e uma
} 
De fato, ainda que o cristianismo tenha representado muito mais uma doutrina de redenção do que um modelo de ciência política, dele é possível extrair importantes reflexões sobre várias categorias jurídico-políticas, como o governo, a autoridade, a lei humana e a obediência. Para a filosofia cristã, todo o poder constituído vem de Deus, que legitima os governos, deixando ao povo o dever de obediência e subordinação à autoridade em exercício. Segundo Antonio Carlos Wolkmer, pode-se buscar em Santo Agostinho (354 - 430 d.C.) um importante legado teórico à noção de legalidade. Para o Bispo de Hipona, a lei primeira é a lei eterna, que expressa a razão divina e a vontade de Deus, manifestando-se na intimidade da consciência humana como lei natural. A lei natural seria a participação da razão humana na ordem divina do universo, servindo de fundamento para as leis humanas ou temporais. Deste modo, o Direito positivo teria como base e fundamento o Direito natural, que nada mais representaria do que um aspecto da lei eterna. Portanto, para o pensamento agostiniano, se a lei humana é justa e legítima, é porque deriva da lei natural e da vontade de Deus. ${ }^{44}$

Mas somente com o pensamento de Santo Tomás de Aquino (1224-5 - 1274 d.C.) é que surge uma sólida doutrina teológica do poder, do Estado e uma visão racionalista da legalidade, categorias essenciais à construção da sua teoria política. Com firmes esteios na filosofia aristotélica, a doutrina tomista sustenta que o poder em sua essência tem origem divina, mas é captado e se realiza por meio da própria natureza do homem, capaz de seu exercício e sua aplicação.

Ainda que a obra de Tomás de Aquino não tenha reservado um tratado específico sobre filosofia política, da reconstrução sistemática da sua teoria é possível extrair uma doutrina acerca do conceito de "bem comum". Conforme já acentuado, de matriz

incorporação rígida à tutela da Igreja, buscam desenvolver, sistematicamente, uma doutrina apologética (com implicações na Sociedade, na Política, no Direito e na Ética) que sirva de fundamento filosófico à teologia, procurando criar novas verdades para a religião cristã, impondo e explicando dogmas que regulamentam e institucionalizam a fé católica". Com influência marcante do pensamento de Platão, Cícero e São Paulo, o principal expoente da Patrística foi Santo Agostinho. Na segunda etapa da Idade Média, entre os séculos XI e XIV, a Escolástica representou o ápice da produção intelectual, filosófica e teológica, sobretudo da Europa cristã dos séculos XII e XIII. A filosofia era colocada a serviço da teologia, no sentido de que deveria auxiliar, a partir de um modelo de raciocínio lógico formal, na autenticidade dos dogmas cristãos, pelo que o edifício da fé passou a ser erigido sobre um fundamento racional filosófico, de destacada inspiração aristotélica. Santo Tomás de Aquino foi o principal expoente do pensamento escolástico e um dos mais importantes pensadores do período medieval. Nesse sentido: WOLKMER, Antonio Carlos. O pensamento político medieval: Santo Agostinho e Santo Tomás de Aquino. In: WOLKMER, Antonio Carlos. Introdução à história do pensamento político. Rio de Janeiro: Renovar, 2003. p. 42-52.

${ }^{44} \mathrm{~A}$ marca do pensamento agostiniano é o dualismo maniqueísta da cidade celestial (lgreja), que se ocupa dos interesses espirituais, e da cidade civil (o Estado temporal), que se ocupa das coisas materiais. Somente no final dos tempos é que a cidade de Deus - formada pelos descendentes de Abel - subsistirá. Disso decorre a razão pela qual o Estado deve conhecer limites que não existem para a Igreja. O poder temporal somente poderá integrar-se à cidade de Deus se estiver prostrado e subordinado à Igreja em todos os assuntos ou questões espirituais. WOLKMER, Antonio Carlos. O pensamento político medieval: Santo Agostinho e Santo Tomás de Aquino. In: WOLKMER, Antonio Carlos. Introdução à história do pensamento político. Rio de Janeiro: Renovar, 2003. p. 47-50. 
largamente influenciada pelo pensamento aristotélico, a filosofia tomista concebe o homem como ser intelectual (ser subsistente na natureza racional), o mais perfeito dentre todos os que habitam a natureza criada, que somente atingirá sua finalidade última e suprema conhecendo e amando a Deus. O homem (na qualidade de ser racional) torna-se o único dentre todos os seres naturais dotado do poder de alcançar o "bem comum perfeito" (bonum commune perfectum), que é a felicidade ou beatitude. Porém, a noção tomista de bem comum não se encerra sob um modelo de felicidade exclusivamente temporal (bem comum relativamente perfeito), já que somente será possível a verdadeira felicidade (perfeita) ao homem que alcançar o bem comum por essência, que é Deus. ${ }^{45}$

Nesse sentido, pode-se dizer que a filosofia tomista "colocava o bem comum como tudo aquilo que o homem deseja, seja de que natureza for: bem material, moral, espiritual, intelectual. Mas, sendo o homem um ser social, ele procura não só o seu próprio bem, mas também aquele do grupo a que pertence. Cada grupo tem o seu próprio bem comum". 46

Para a doutrina política tomista, na qualidade de "animal político aristotélico", o homem encontra a paz e a união na convivência em comunidade (civitas), a partir de uma sociedade politicamente organizada (Estado), sobre as bases de um modelo de governo (autoridade) e um conjunto de leis (Direito). No pensamento político de Tomás de Aquino, o seu modelo racionalista de legalidade ${ }^{47}$ desempenha um papel central, já que o homem seria conduzido à paz e ao bem comum relativamente perfeito, que é a felicidade terrena, se ordenado pela lei humana objetiva (regulatória da convivência na sociedade), promotora da justiça e definidora das obrigações que cada indivíduo (parte) tem com a comunidade (todo).

De fato, a noção de legalidade em Tomás de Aquino assume contornos de relevante interesse, inclusive para a compreensão da própria ideia de Direito. Na doutrina tomista, a lei consiste na razão, na qualidade de capacidade de leitura e medida do real, uma noção sensivelmente ligada a uma concepção de razoabilidade e justiça, que não

\footnotetext{
${ }^{45}$ GALÁN Y GUTIÉRREZ, Eustaquio. La filosofia política de Sto. Tomás de Aquino. Madrid: Editorial Revista de Derecho Privado, 1945. p. 56-59.

${ }^{46}$ DI PIETRO, Maria Sylvia Zanella. O princípio da supremacia do interesse público: sobrevivência diante dos ideais do neoliberalismo. In: DI PIETRO, Maria Sylvia Zanella; RIBEIRO, Carlos Vinícius Alves (Coord.). Supremacia do interesse público e outros temas relevantes do direito administrativo. São Paulo: Atlas, 2010. p. 87.

${ }^{47} \mathrm{Na}$ doutrina tomista, a lei eterna constitui-se na razão suprema existente em Deus, situada acima de todas as outras leis, regente e reguladora da ordem da criação divina. Por seu turno, a lei natural seria a manifestação incompleta e imperfeita da lei eterna em todos os homens, um produto da razão humana e comum em cristãos e pagãos. Derivada e inspirada na lei natural, a lei humana teria por finalidade presidir as ações e os atos humanos, a ser completada e complementada pela lei divina (que não advém da razão), como revelação das Sagradas Escrituras e destinada a sanar as imperfeições da lei humana. Nesse sentido: WOLKMER, Antonio Carlos. O pensamento político medieval: Santo Agostinho e Santo Tomás de Aquino. In: WOLKMER, Antonio Carlos. Introdução à história do pensamento político. Rio de Janeiro: Renovar, 2003. p. 54-56.
} 
se esgota somente em "forma e comando; é, antes de tudo, um conteúdo substancial determinado porque é, antes de mais nada, leitura da realidade" ${ }^{48}$

Deste modo, seria possível afirmar que somente em sociedades perfeitas existem leis justas, que têm como ponto basal o bem comum; e somente será uma "comunidade perfeita" aquela que ordenar e promover a ação política dos seus cidadãos para o bem comum. Nada obstante, disso não se pode deduzir que em uma comunidade política todos os cidadãos tenham os mesmos valores ou objetivos, mas que existe um conjunto de bens (finalidades, objetivos) que lhes são comuns, notadamente aqueles capazes de conduzir os cidadãos a sua finalidade última: a felicidade ou beatitude. ${ }^{49}$

\title{
4. A RECONSTRUÇÃO DA NOÇÃO DE BEM COMUM NO PENSA- MENTO POLÍTICO MODERNO: A MORALIDADE POLÍTICA EM MAQUIAVEL E O CONCEITO DE VONTADE GERAL EM ROUSSEAU
}

No pensamento político renascentista, coube a Nicolau Maquiavel (1469 - 1527 d.C.) formular uma das mais influentes doutrinas políticas legadas à Modernidade. ${ }^{50}$

\begin{abstract}
${ }^{48}$ Com base nessa relação entre as noções de lei, justiça e Direito do Medievo e da Modernidade, o jurista e historiador do Direito Paolo Grossi faz uma interessante e profunda análise crítica do Estado moderno e do papel do Direito na Modernidade, que estaria intimamente vinculado ao poder político, como comando hierarquizado de um superior a um inferior, a partir de uma regra jurídica fundada na autoridade. Uma noção que abandona a dimensão sapiencial do Direito, do justo, do razoável, da razão como medida do real, limitando-se a uma forte e monolítica expressão da juridicidade, a lei. A lei dos modernos é antes ato de vontade (autoridade legislativa) do que ato de conhecimento (sapiência do Direito, justiça). A sua força não está no conteúdo (o que é dito), mas no fato de provir do órgão máximo de poder político. A Modernidade teria reduzido o Direito à lei, apartando-o da ideia de justiça. O que "o Estado moderno assegura aos cidadãos é somente um complexo de garantias formais", ou seja, um ato de autoridade formulado com base em determinados procedimentos, onde o seu conteúdo, a correspondência ao que a consciência comum reputa como o justo (a justiça da lei), isso é somente um objetivo exterior do ordenamento jurídico. Nesse sentido: GROSSI, Paolo. Mitologias jurídicas da Modernidade. Tradução de Arno Dal Ri Júnior. Florianópolis: Fundação Boiteux, 2004. p. 13-37. Para o estudo a partir de outra abalizada análise crítica do Direito e sua relação com o Estado, com base em uma matriz historicista, com especial atenção para a crise de legitimidade do discurso jurídico na Modernidade, consultar: ROULAND, Norbert. Nos confins dos Direito: antropologia jurídica da Modernidade. Tradução de Maria Ermantina de Almeida Prado Galvão. São Paulo: Martins Fontes, 2003.
\end{abstract}

${ }^{49}$ TOMÁS DE AQUINO, Santo. Suma teológica. t. VI. Madrid: B.A.C., 1956. p. 38-42.

${ }^{50}$ Pode-se dizer que Maquiavel nunca pretendeu simplesmente a formação teórica de um tipo ideal de novo príncipe. Dotado de um método de observação da realidade, o filósofo florentino discute a possibilidade de o ser humano intervir na sua trajetória. Diferente dos antigos, que possuíam uma visão cíclica do tempo segundo a qual tudo apresentava um nascer, crescer, morrer e renascer, e dos judeus e cristãos, que entendiam o tempo de uma forma linear, no sentido de que Deus criou o mundo em algum momento e este terá fim (noção de partida e chegada), os renascentistas viam o tempo como algo dinâmico, em que os homens poderiam interferir em seus destinos. $\mathrm{O}$ tempo possui um curso determinando, mas que poderia ser modificado pelo homem, como um rio que pode ser desviado, em partes, de seu leito natural. Letícia de Campos Velho Martel ressalta que, para Maquiavel, todos os governos são perecíveis, mas está nas mãos do príncipe retardar a queda certa. O secretário florentino recupera a alegoria da Antiguidade, que via a fortuna (sorte) como uma mulher seduzível e influenciável, descrita pelo filósofo como dominável e domável. Já não é mais o destino o condutor do homem; este é que transforma o destino, agindo de forma dinâmica sobre o tempo. O príncipe é o senhor da sua sorte e não a Providência Divina. Afora a noção de fortuna, a virtude (virtù) é outra categoria nuclear no pensamento político maquiaveliano. Como a fortuna não é de todo imprevisível, 
Ainda que não tenha construído uma teoria do "bem comum", é possível extraí-la do modelo de moralidade política presente na obra O Príncipe, de inequívoca repercussão em toda a filosofia política que a sucedeu.

O "realismo" maquiaveliano (verdade efetiva das coisas) e sua análise consequentemente "pessimista" da "natureza humana"51 oferecem os ingredientes centrais para o modelo de moralidade política inaugurado pelo Filósofo Florentino, a partir de um conceito de moral diretamente relacionado com as necessidades da ação política, reguladora dos interesses do Estado e não submetida aos parâmetros da moral cristã e aos desígnios da Divina Providência.

Nesse sentido, ao homem (e ao príncipe/governante em especial) seria legítimo usar de todos os meios necessários para atingir os seus objetivos, cabendo-lhe ser "suficientemente prudente para evitar a infâmia daqueles vícios que lhe tirariam o poder e guardar-se, na medida do possível, daqueles que lhe fariam perdê-lo",52 mas não devendo aborrecer-se por cometer aquelas ações sem as quais lhe seria difícil conservar o poder, pois é possível encontrar "alguma coisa que parecerá virtù e, sendo praticada, levaria à ruína; enquanto uma outra que parecerá vício, quem a praticar poderá alcançar segurança e bem estar".53

Por outro lado, não parece adequado dizer que Maquiavel entende a ação política dissociada da moralidade ou avessa a ela, como se estivesse a defender pura e

a virtude seria a qualidade do homem (o príncipe) de perceber a situação que está em formação, traçar uma estratégia e agir (resposta) no momento oportuno. A virtude é a qualidade de alguns homens de prever o mal e remediá-lo a tempo. Mas isso depende de um aguçado senso de oportunidade (ocasião - terceira categoria central). A ocasião é a ponte entre a virtude e a fortuna, já que pouco resultaria da previsão do problema, sem desvendar o momento certo de agir. Na moralidade política de Maquiavel, o príncipe é um político, um homem que domina as técnicas da política e age em prol do bem de seu estado, a manutenção do Estado. O filósofo florentino rompe com a doutrina da Providência Divina e defende que as rédeas do destino estão nas mãos dos homens, que podem agir e medir as consequências de suas ações na relação com os outros homens, cabendo ao político destacar-se em meio aos homens comuns, já que dele se exige mais ação e mais virtude. Nesse sentido: MARTEL, Letícia de Campos Velho. O tempo e a política no pensamento de Maquiavel. In: WOLKMER, Antonio Carlos (Org.). Introdução à história do pensamento político. Rio de Janeiro: Renovar, 2003. p. 74-89.

51 Sobre o pessimismo maquiaveliano acerca da natureza humana e as qualidades necessárias ao Príncipe, disse o secretário florentino: "Isto porque geralmente se pode afirmar o seguinte acerca dos homens: que são ingratos, volúveis, simulados e dissimulados, fogem dos perigos, são ávidos de ganhar e, enquanto lhes fizeres bem, pertencem inteiramente a ti, te oferecem o sangue, o patrimônio, a vida e os filhos, desde que o perigo esteja distante; mas quando precisas deles, revoltam-se. [...] Os homens têm menos receio de ofender a quem se faz amar do que a outro que se faça temer; pois o amor é mantido por vínculo de reconhecimento, o qual, sendo os homens perversos, é rompido sempre que lhes interessa, enquanto o temor é mantido pelo medo ao castigo, que nunca te abandona. [...] Se precisar derramar o sangue de alguém, deverá fazê-lo quando houver justificativa conveniente e causa manifesta. Mas, sobretudo, deverá respeitar o patrimônio alheio, porque os homens esquecem mais rapidamente a morte do pai do que a perda do patrimônio". MAQUIAVEL, Nicolau. $\mathbf{O}$ Príncipe. Tradução de Maria Júlia Goldwasser. 3. ed. 2. tir. São Paulo: Martins Fontes, 2008. p. 80-81.

${ }^{52}$ MAQUIAVEL, Nicolau. O Príncipe. Tradução de Maria Júlia Goldwasser. 3. ed. 2. tir. São Paulo: Martins Fontes, 2008. p. 74.

${ }^{53}$ MAQUIAVEL, Nicolau. O Príncipe. Tradução de Maria Júlia Goldwasser. 3. ed. 2. tir. São Paulo: Martins Fontes, 2008. p. 74. 
simplesmente a autonomia da política em relação à moralidade. Realmente, a partir de um modelo analítico-realista do agir político e de sua legitimação, parece que o secretário florentino propõe sim uma moralidade política que rompe com a então reinante tradição ocidental da moral cristã (piedade, compaixão e bondade dos homens), quando defende ser lícito e legítimo ao governante usar de todos os meios necessários para "manter o seu estado", para "realizar grandes feitos" e perseguir as "elevadas metas da honra, glória e fama", pelo que o "contraste essencial diz respeito, isso sim, a duas moralidades distintas - duas exposições antagônicas e incompatíveis do que em última análise se deve fazer".54

Contudo, há na teoria política maquiaveliana uma indagação central: o que legitimaria as ações políticas do governante para "manter o seu estado"? Diversamente de uma teoria de justificação para os governos tirânicos, para o secretário florentino os fins últimos e legitimadores das ações políticas do príncipe para manter o seu Estado não estariam nos interesses egoísticos e privados do próprio governante, mas na glória do seu povo, ou seja, na manutenção do seu Estado e na propagação do bem comum..$^{55}$

Ainda que o pensamento político maquiaveliano não ofereça um conceito acabado de "bem comum", da sua obra é possível extraí-lo tanto a partir da relação com um forte senso de patriotismo/nacionalismo (amor à pátria), impondo-se ao governante a renúncia aos seus interesses meramente egoísticos (glória pessoal) em prol da glória da pátria; como da preocupação com a construção de instituições políticas (governos) duradouras, capazes de legar às gerações futuras a estabilidade política e a segurança necessárias à manutenção do Estado. ${ }^{56}$

De fato, na doutrina maquiaveliana a noção de bem comum tem seu epicentro significativo nas ideias de "glória da pátria" e "salvação do Estado", com vistas à estabilidade das instituições políticas e aos seus grandes feitos, o que legitima e justifica as práticas políticas do governante (ainda que injustas, cruéis ou ignominiosas). A ação exitosa do governo no sentido de manter ao máximo possível a unidade e a segurança da nação representaria o próprio fim último do Estado. Isso, inclusive, levou estudiosos da evolução histórica do pensamento político a atribuir ao secretário florentino a

\footnotetext{
${ }^{54}$ SKINNER, Quentin. As fundações do pensamento político moderno. Tradução de Renato Janine Ribeiro e Laura Teixeira Motta. 1. reimp. São Paulo: Companhia das Letras, 1999. p. 155.

${ }^{55}$ CRISTÓVAM, José Sérgio da Silva; KAESTNER, Roberto Nasato. A busca pelo verdadeiro Príncipe: uma contraposição entre virtù e fortuna. In: MACHADO, Nivaldo et al. (Org.). Pensar o Direito. Rio do Sul: Editora UNIDAVI, 2011. p. 66-71.

${ }^{56}$ Esses elementos políticos formadores da noção de "bem comum" no pensamento maquiaveliano ficam evidentes em várias passagens da obra O Príncipe, sintetizando-se, inclusive, no seu Capítulo XXVI, em que o filósofo exorta um "novo príncipe" a tomar a Itália e libertá-la das mãos dos bárbaros. Nesse sentido: MAQUIAVEL, Nicolau. O Príncipe. Tradução de Maria Júlia Goldwasser. 3. ed. 2. tir. São Paulo: Martins Fontes, 2008. p. 123-127.
} 
antecipação das bases teóricas para o que posteriormente ficou conhecido como a "teoria das razões de Estado".57

Na trilha da reconstrução histórica da noção de "bem comum", outra original contribuição filosófica à formação do pensamento político se encontra na doutrina de Jean-Jacques Rousseau (1712 - 1778 d.C.), sobretudo na sua obra Do Contrato Social. ${ }^{58}$ A teoria rousseauniana sustenta a existência de um "estado de natureza" anterior à formação da sociedade (estado civil). Entretanto, o homem natural do contratualismo rousseauniano é o oposto do "lobo do homem" descrito por Thomas Hobbes (1588 1679 d.C.) no seu Leviatã..$^{59}$ Trata-se de um indivíduo que naturalmente preserva seu

\begin{abstract}
${ }^{57}$ Para uma contextualização introdutória da teoria das razões de Estado, vale ressaltar: "A tradição de pensamento indicada pela expressão Razão de Estado compreende todo o curso histórico da Europa moderna e das áreas a ela culturalmente ligadas (a América particularmente). Nela se pode distinguir algumas linhas particularmente significativas. O ponto de partida se situa no limiar da Idade Moderna e é constituído pelas instituições geniais e inspiradoras de Maquiavel, com que começa a emergir, em seus contornos mais gerais, o conceito de Razão de Estado, mas não ainda a sua exata formulação verbal [...] O segundo momento especialmente significativo desta tradição está na reflexão e análises dos mestres da razão e dos interesses de Estado, em sua maioria italianos e franceses, da segunda metade do século XVI e do século XVII [...] Esta doutrina atingiu depois um momento de enorme esplendor e de um altíssimo nível de conceituação na cultura alemã do século XIX e primeira metade deste". BOBBIO, Norberto; MATTEUCCI, Nicola; PASQUINO, Gianfranco. Dicionário de Política. Tradução de João Ferreira. v. I. 11. ed. Brasília: Editora Universidade de Brasília, 1998. p. 1067. Para uma análise da teoria das razões de Estado a partir das obras de Maquiavel e de Giovanni Botero, consultar: NUNES, Diego. Entre "O Príncipe" e a "Razão de Estado": apontamentos sobre a arte de governar entre as obras de Maquiavel e Botero. Revista Discente do Curso de Pós-Graduação em Direito da UFSC, Florianópolis, ano 1, n. 1, p. 126-145, jul./dez. 2008.
\end{abstract}

${ }^{58} \mathrm{O}$ pensamento rousseauniano sofre críticas relacionadas à ausência de unidade, coerência e totalidade sistemática na sua teoria política, a partir de uma contradição entre os principais textos políticos de ROUSSEAU (O Discurso sobre a Origem da Desigualdade e Do Contrato Social), já que no primeiro o filósofo apresenta um pessimismo antissocial que contrasta com o otimismo evidenciado no segundo. Na verdade, a compreensão adequada dos principais conceitos da segunda obra está diretamente vinculada à problemática desenvolvida na primeira. O Contrato Social deve ser lido como uma proposta de sociedade ideal, uma utopia alternativa, onde a liberdade e a igualdade se articulem indissociavelmente, no plano do dever ser, ao passo que O Discurso retrata a realidade daquele momento histórico (sociedade civil da época), situado no plano do ser. Nesse sentido: HAUSER, Ester Eliana. O ideal democrático no pensamento político de Jean-Jacques Rousseau. In: WOLKMER, Antonio Carlos (Org.). Introdução à história do pensamento político. Rio de Janeiro: Renovar, 2003. p. 168.

${ }^{59}$ Inegavelmente, Hobbes foi um autor polêmico e seu pensamento político transcendeu os debates do seu tempo, chegando até os dias atuais. A teoria política hobbesiana parte da análise do homem para explicar o Estado (Leviatã). Nas palavras de André Lipp Pinto Basto LUPI: "Pois se o Leviatã é o homem artificial construído por todos, seria preciso, conforme o método cartesiano, desmembrá-lo em partes para entender o todo. $\mathrm{E}$ a parte do Leviatã é cada um dos homens que o compõe". Na sua análise do homem, aproxima-se de Maquiavel, sendo que ambos "consideravam o homem um ser egoísta, predisposto a cometer atos antissociais. Aliada ao princípio da autopreservação, esta noção permite que Hobbes deduza a figura da guerra de todos contra todos, um estado de natureza em que cada homem luta pela sua sobrevivência, sem que haja barreiras sociais para impedir a sua atuação, mesmo quando age contra o seu semelhante". A competição, a desconfiança e a glória são as razões da discórdia na natureza do homem. Hobbes cita o Leviatã das escrituras de Jó (o Rei de todos os filhos da soberba) como poder soberano capaz de manter (viabilizar) a vida em sociedade, por meio da coerção (monopólio da lei nas mãos do monarca soberano). Na teoria hobbesiana, o pior de todos os males seria a guerra civil, a disputa de todos contra todos (estado de natureza). Para caracterizá-la, o filósofo busca a representação do monstro Behemot (símbolo da rebelião), que deve ser dominado por Leviatã. Se o pior dos males é a guerra civil, isso justificaria a criação do Estado, uma autoridade forte que, ainda que viesse a tolher a liberdade, garantiria a segurança e a vida dos homens. Para proteger-se da insegurança do estado de natureza, o homem pactua a criação de um soberano absoluto para sua defesa e segurança (Leviatã), com a cessão de 
bem-estar e conservação (o amor de si, diferente de amor próprio), bem como age com sentimento de piedade em relação aos seus semelhantes.

Para Rousseau, o homem não se organiza em sociedade para se proteger dos seus semelhantes, para garantir sua propriedade, mas para melhor enfrentar as forças da natureza e mais facilmente vencer os obstáculos naturais. Nesse processo de socialização, o homem sai do seu isolamento e torna-se dependente dos outros, uma socialização anterior e preparatória ao contrato social. Desta fase podem seguir dois "modelos ideais" de contrato: um contrato iníquo, do qual resulta uma sociedade injusta, onde os indivíduos são alijados da liberdade e da igualdade; e um contrato legítimo, capaz de gerar uma sociedade que respeite e fomente os fundamentos naturais do indivíduo, uma sociedade igualitária (igualdade política e substancial) e base de uma política fundada no interesse comum (estado civil do Contrato Social)..$^{60}$

No pensamento político rousseauniano não há lugar para a autoridade de um homem sobre os demais a não ser pela via de uma convenção (acordo livre e consciente). No estado civil (sociedade civil), o indivíduo não perde sua liberdade, apenas deixa a sua "liberdade natural" (limitada e garantida apenas por sua própria força) para adquirir a "liberdade civil", um modelo de "liberdade moral" que é limitada apenas pela "vontade geral". Essa vontade geral do corpo político (cidadãos) constitui-se na expressão da soberania na sociedade civil ideal. Mas a soberania da vontade geral não se coaduna com a ideia de propriedade ilimitada, nem com uma sociedade desigual em níveis de riqueza. A propriedade e a riqueza devem estar subordinadas ao interesse comum, sob pena de o interesse particular sobrepor-se ao interesse geral. ${ }^{61}$

Realmente, a noção de "vontade geral" é central à filosofia política rousseauniana, representando mesmo a pedra de toque e o coração da democracia no contrato social de Rousseau. Constitui-se no canal de interação dos interesses que cada pessoa tem em comum com as demais, pelo que a promoção do seu interesse reflete nos interesses de todas as outras pessoas, traduzindo o que há de comum no conjunto das

\footnotetext{
parte de sua liberdade em troca de segurança. O Estado criado pelo pacto social é o homem artificial, o Estado formado pelo pacto de cada um dos homens que o compõe. Nesse sentido: LUPI, André Lipp Pinto Basto. Uma abordagem contextualizada da teoria política de Thomas Hobbes. In: WOLKMER, Antonio Carlos (Org.). Introdução à história do pensamento político. Rio de Janeiro: Renovar, 2003. p. 103-129; HOBBES, Thomas. Leviatã ou matéria, forma e poder de um Estado eclesiástico e civil. Tradução de João Paulo Monteiro e Maria Beatriz Nizza da Silva. 2. ed. São Paulo: Martins Fontes, 2008.

${ }^{60}$ ROUSSEAU, Jean-Jacques. O contrato social ou princípios de Direito Público. Tradução de Antonio de Pádua Danesi. 3. ed. 3. tir. São Paulo: Martins Fontes, 1999. p. 20-26.

${ }^{61} \mathrm{Na}$ doutrina política de Rousseau, cada membro do corpo político é cidadão e súdito: cidadão porque membro do soberano e participante da atividade do corpo político; súdito porque obediente às leis votadas pelo corpo político. Como o indivíduo, submete-se às leis que ele mesmo votou, é soberano de si mesmo, não perdendo com isso a sua liberdade. Frente à assembleia (parte ativa do corpo político) o indivíduo é soberano, frente ao Estado (parte passiva) é súdito. Nesse sentido: HAUSER, Ester Eliana. O ideal democrático no pensamento político de Jean-Jacques Rousseau. In: WOLKMER, Antonio Carlos (Org.). Introdução à história do pensamento político. Rio de Janeiro: Renovar, 2003. p. 176-177.
} 
vontades individuais. Trata-se da manifestação do corpo soberano do Estado (povo), sendo um poder indivisível e inalienável, pelo que "só a vontade geral pode dirigir as forças do Estado em conformidade com o objetivo de sua instituição, que é o bem comum: pois, se a oposição dos interesses particulares tornou necessário o estabelecimento das sociedades, foi o acordo desses mesmos interesses que o tornou possível".62

Na teoria contratualista ${ }^{63}$ rousseauniana, a vontade geral não prescinde de dois componentes legitimadores da sua instauração: primeiro, a ideia de que a participação de todos na soberania do corpo social (igualdade política) deve ser acompanhada de um determinado nível de igualdade substancial, imprescindível para assegurar a própria participação e a igualdade política entre os cidadãos; segundo, um princípio racional de moralidade política, que mantém a vontade geral a salvo de todos aqueles interesses diversos do verdadeiro interesse comum.

Assim, para uma melhor compreensão da noção de vontade geral na teoria política de Rousseau, é necessário lançar luzes sobre os contornos das suas categorias laterais: a "vontade particular", a "vontade corporativa" e a "vontade de todos".

A vontade particular é a vontade privada ou pessoal do indivíduo (cidadão), que não propende senão ao seu proveito particular, o desejo de alcançar e satisfazer os seus interesses e vantagens pessoais, sem a consideração por desejos ou interesses alheios que não Ihe possam aproveitar diretamente. Por conseguinte, embora a vontade particular possa até mostrar-se eventual e pontualmente de acordo com a vontade geral, é impossível que isso seja constante e duradouro, já que enquanto a vontade geral pugna pela igualdade (igualdade política e substancial), àquela interessam predileções e favorecimentos. Há, ainda, os casos de conflito entre a vontade particular e a vontade

\footnotetext{
${ }^{62}$ ROUSSEAU, Jean-Jacques. O contrato social ou princípios de Direito Público. Tradução de Antonio de Pádua Danesi. 3. ed. 3. tir. São Paulo: Martins Fontes, 1999. p. 33.

${ }^{63}$ Ainda que transborde os limites da presente abordagem, convém pelo menos traçar as linhas gerais do contratualismo, como escola do pensamento político moderno. Nesse sentido: “Com o Contratualismo tornou-se comum identificar teorias muito diversas entre si [...] Em sentido muito amplo o Contratualismo compreende todas aquelas teorias políticas que vêem a origem da sociedade e o fundamento do poder político (chamado, quando em quando, potestas, imperium, Governo, soberania, Estado) num contrato, isto é, num acordo tácito ou expresso entre a maioria dos indivíduos, acordo que assinalaria o fim do estado natural e o início do estado social e político. Num sentido mais restrito, por tal termo se entende uma escola que floresceu na Europa entre os começos do século XVII e os fins do XVIII e teve seus máximos expoentes em J. Althusius (1557-1638), T. Hobbes (1588-1679), B. Spinoza (1632-1677), S. Pufendorf (1632-1694), J. Locke (1632-1704), J.-J. Rousseau (1712-1778), I. Kant (1724-1804) [...] É igualmente necessário fazer uma distinção analítica entre três possíveis níveis explicativos; há os que sustentam que a passagem do estado de natureza ao estado de sociedade é um fato histórico realmente ocorrido, isto é, estão dominados pelo problema antropológico da origem do homem civilizado; outros, pelo contrário, fazem do estado de natureza mera hipótese lógica, a fim de ressaltar a ideia racional ou jurídica do Estado, do Estado tal qual deve ser, e de colocar assim o fundamento da obrigação política no consenso expresso ou tácito dos indivíduos a uma autoridade que os representa e encarna; outros ainda, prescindindo totalmente do problema antropológico da origem do homem civilizado e do problema filosófico e jurídico do Estado racional, veem no contrato um instrumento de ação política capaz de impor limites a quem detém o poder. BOBBIO, Norberto; MATTEUCCI, Nicola; PASQUINO, Gianfranco. Dicionário de Política. Tradução de João Ferreira. v. I. 11. ed. Brasília: Editora Universidade de Brasília, 1998. p. 272.
} 
geral, situações de elevado risco, sobretudo naquelas situações em que os atores interessados possam buscar subverter a vontade geral ou disfarçada e sorrateiramente fraudá-la e substituí-la pela vontade particular por meio de argumentos e composições de ocasião. ${ }^{64}$

Por sua vez, a vontade corporativa é aquela que decorre dos interesses comuns de um grupo de pessoas (corporação), que ostentam desejos comuns tanto distintos daqueles que todas as pessoas têm como membros do Estado (sociedade civil), como também diversos dos interesses de cada indivíduo nessa qualidade (separadamente). As vontades corporativas traduzem interesses gerais em relação ao grupo e particulares se confrontados ao Estado (todo dos cidadãos), não podendo ser confundidos com a vontade geral. Ainda que não habitem um necessário campo de colisão, a doutrina rousseauniana condena com veemência todo o tipo de "facções",65 deturpadoras e escamoteadoras da vontade geral. Esta não pode ser identificada naquelas "decisões majoritárias que, num contexto só aparentemente democrático, encerram uma confrontação eleitoral ou um debate político, devendo-se considerar, portanto, irrelevantes, do ponto de vista da vontade geral, as decisões tomadas num clima político dominado por facções".66

Mas a distinção por excelência e mais complexa da teoria política de Rousseau está na contraposição entre a vontade de todos e a vontade geral. Diferente da vontade geral (interesse comum), a vontade de todos reflete interesses privados e não passa de uma soma das vontades particulares. Conquanto possam até coincidir, ainda que aproximadamente, com os interesses da vontade geral (interesse comum), os interesses da vontade de todos acabam por refletir e veicular somente desejos privados que são "comungados" de forma instável e contingencial (relativa), pelo que o "interesse comum não é o interesse de todos, no sentido de uma confluência dos interesses particulares, mas o interesse de todos e de cada um como componentes do corpo coletivo e exclusivamente nesta qualidade", o que alerta para o inegável "perigo de predominar o interesse da maioria, pois, se é sempre possível conseguir a concordância dos interesses privados de um grande número, nem por isso assim se estará atendendo ao interesse comum".67

\footnotetext{
${ }^{64}$ PINTO, Maurício Morena. A noção de vontade geral e seu papel no pensamento político de Jean-Jacques Rousseau. Cadernos de Ética e Filosofia Política do Programa de Pós-Graduação do Departamento de Filosofia da USP, São Paulo, n. 7, p. 83-97, 2. sem. 2005. p. 86-87.

${ }^{65}$ Ultrapassa os limites do presente estudo o debate mais aprofundado sobre a questão das "facções" em Rousseau e no pensamento de outros filósofos da Modernidade. Sobre o tema, consultar: PINZANI, Alessandro. Os demônios e as facções: Kant e Madison sobre paixões e instituições. Crítica: Revista de Filosofia da Universidade Estadual de Londrina, v. 11, n. 33, p. 131-152, 2006.

${ }^{66}$ PINTO, Maurício Morena. A noção de vontade geral e seu papel no pensamento político de Jean-Jacques Rousseau. Cadernos de Ética e Filosofia Política do Programa de Pós-Graduação do Departamento de Filosofia da USP, São Paulo, n. 7, p. 83-97, 2. sem. 2005. p. 87.

${ }^{67}$ PINTO, Maurício Morena. A noção de vontade geral e seu papel no pensamento político de Jean-Jacques Rousseau. Cadernos de Ética e Filosofia Política do Programa de Pós-Graduação do Departamento de Filosofia da USP, São Paulo, n. 7, p. 83-97, 2. sem. 2005. p. 89.
} 
Não se trata, pois, de pretender uma unanimidade de ideias em torno da vontade geral (interesse comum legítimo). A questão é muito menos numérica e matemática e muito mais ética e política. Do conjunto de inevitáveis divergências que compõem o complexo mosaico dos legítimos desejos e interesses de uma comunidade política (corpo social), a expressão da vontade geral estará naquele conjunto de elementos de consenso ou interesses comuns para os quais converge a sociedade.

Nada obstante, essa noção de bem comum a partir do conceito rousseauniano de vontade geral acaba por sofrer duras críticas, taxada de um modelo individualista de matriz claramente utilitarista, na medida em que supera e afasta aquela ideia tomista de bem comum, impregnada de um cunho moral e ideológico (solidariedade social), pela máxima da vontade geral, que teria no viés utilitário e legalista do consentimento (contrato) o seu fundamento de legitimação. Uma legalidade que adquire um caráter quase sagrado, típico do liberalismo individualista (a racionalidade da lei assumiria uma feição de divindade incontestável), "inteiramente desvinculado de qualquer conteúdo axiológico; ela vale por si mesma. Idealizada como instrumento de proteção das liberdades individuais, acaba por colocar em risco essas mesmas liberdades, tornando-se instrumento de opressão".68

Embora razoáveis, não parece que estas críticas caibam diretamente no pensamento rousseauniano, no sentido de reduzi-lo a mais acabada doutrina liberal-individualista de feições utilitaristas, pois não se pode olvidar que a teoria política de Rousseau conduz à construção de um conceito de vontade geral sobre o fundamento de um insuprimível componente moral, que exige a construção da sociedade a partir de um modelo de igualdade substancial.

Por outro lado, também parece inegável que, sem esse componente moral, o edifício teórico rousseauniano desmoronaria e sucumbiria facilmente à dinamite totalitária e autoritária das maiorias de ocasião, tão comuns na atualidade, que falseiam e encobrem interesses egoísticos e parciais sob uma densa cortina de fumaça, envolvidos sob os quase sempre oscilantes e casuísticos contornos de um "interesse público", aparentemente revelado de forma mítica ou divina por autoridades usurpadoras da legítima e democrática vontade, construída a partir do consenso soberano do povo e assentada nas Constituições contemporâneas.

\section{CONSIDERAÇÕES FINAIS}

De toda essa (breve) recuperação histórica do rico pensamento político ocidental, pode-se conceber que a noção de bem comum constitui-se a partir de uma constante moral, um conceito indeterminado (mas determinável) que guarda destacada

${ }^{68}$ DI PIETRO, Maria Sylvia Zanella. O princípio da supremacia do interesse público: sobrevivência diante dos ideais do neoliberalismo. In: DI PIETRO, Maria Sylvia Zanella; RIBEIRO, Carlos Vinícius Alves (Coord.). Supremacia do interesse público e outros temas relevantes do direito administrativo. São Paulo: Atlas, 2010. p. 88-90. 
relevância e ingerência na relação de integração entre os interesses individuais ou de grupos de pessoas com os interesses gerais de uma comunidade política. Ainda que a noção de bem comum possa trazer em si a ideia de negação e contraposição a interesses individuais ou corporativos, que acabariam por sucumbir aos "interesses maiores" da coletividade, um conceito moralmente legítimo de bem comum deve surgir da afirmação desse caldo de diversidades e (aparentes) contradições de interesses dos mais variados matizes e não da construção de um pensamento unitário ou da unanimidade em torno das questões de interesse coletivo ou geral.

Não se pode jamais esquecer que a construção da coletividade parte do indivíduo, que tem aspirações próprias e legítimas e que não podem ser ignoradas ou sufocadas pelo sentimento coletivo. O adequado balanceamento e composição desses interesses, por vezes conflitantes, parece ser o ponto de equilíbrio necessário à efetiva construção de uma comunidade política justa e capaz de alcançar aquele bem comum supremo aristotélico: a felicidade!

Com efeito, a história recente do século XX está recheada de infelizes exemplos capazes de indicar até onde a maldade humana consegue levar a barbárie e a irracionalidade, a partir da usurpação (degeneração) de teorias (mais ou menos) organicistas de primazia absoluta do interesse público tutelado pelo Estado, ou variáveis utilitaristas fundadas na máxima de que a finalidade das instituições jurídico-políticas está em assegurar a maior felicidade ao maior número de indivíduos.

Esses modelos teóricos, por mais bem intencionados que sejam e ainda que pretendam a felicidade da maioria, trazem no seu DNA um potencial de genética autoritária/totalitária de ofensa a direitos humanos fundamentais, o que não pode ser fundamento legítimo para qualquer conceito de interesse público que se pretenda amparado por um genuíno Estado constitucional de direito.

Inegavelmente, a dinâmica sociopolítica conduz à diversidade e contraposição de interesses, cabendo aos poderes constituídos não a imposição de valores unitários e perpétuos (fundados em verdades monolíticas e excludentes), mas a construção de consensos inclusivos gestados a partir dessa assimetria social. É certo que a convivência democrática de interesses opostos/contrapostos, em especial em uma democracia largamente rarefeita como a brasileira, não é tarefa fácil e nem um caminho só para frente. Marchas, contramarchas, soluços e até cavalos de pau são (até certo ponto) inevitáveis. Este é o nosso trabalho de Hércules.

\section{REFERÊNCIAS}

ARENDT, Hannah. A condição humana. Tradução de Celso Lafer. Rio de Janeiro: Forense, 1983.

ARISTÓTELES. A Política. Tradução de Nestor Silveira Chaves. 2. ed. São Paulo: EDIPRO, 2009.

ARISTÓTELES. Ética a Nicômaco. Tradução de António de Castro Caeiro. São Paulo: Atlas, 2009. 
BARROSO, Luís Roberto. Neoconstitucionalismo e constitucionalização do direito: o triunfo tardio do direito constitucional no Brasil. Boletim da Faculdade de Direito da Universidade de Coimbra, Coimbra, ano 81, p. 233-289, 2005.

BOBBIO, Norberto. Estado, governo, sociedade: para uma teoria geral da política. Tradução de Marco Aurélio Nogueira. 14. ed. Rio de Janeiro: Paz e Terra, 2007.

BOBBIO, Norberto; MATTEUCCI, Nicola; PASQUINO, Gianfranco. Dicionário de Política. Tradução de João Ferreira. v. I. 11. ed. Brasília: Editora Universidade de Brasília, 1998.

BRUNI, Luigino. Bem comum e economia: para uma economia baseada no ágape. Tradução de Luís Miguel Neto. Instituto Superior de Ciências Sociais e Políticas (ISCSP). Universidade Técnica de Lisboa (UTL), Lisboa, p. 01-11, 2008. Disponível em: <http://www.academia.edu/2576914/ Bem_Comum_e_Economia_Para_uma_Economia_baseada_no_Agape_-_trad._do_original_de_ Luigino_Bruno>. Acesso em: 17 jan. 2018.

CARVALHO FILHO, José dos Santos. Interesse público: verdades e sofismas. In: DI PIETRO, Maria Sylvia Zanella; RIBEIRO, Carlos Vinícius Alves (Coord.). Supremacia do interesse público e outros temas relevantes do direito administrativo. São Paulo: Atlas, 2010. p. 67-84.

CHEVALLIER, Jean-Jacques. História do pensamento político. v. 1. Tradução de Roberto Cortes de Lacerda. Rio de Janeiro: Zahar, 1982.

CÍCERO, Marco Túlio. Da República. Tradução de Amador Cisneiros. Bauru: EDIPRO, 1995.

CRISTÓVAM, José Sérgio da Silva. Administração Pública democrática e supremacia do interesse público: novo regime jurídico-administrativo e seus princípios constitucionais estruturantes. Curitiba: Juruá, 2015.

CRISTÓVAM, José Sérgio da Silva; KAESTNER, Roberto Nasato. A busca pelo verdadeiro Príncipe: uma contraposição entre virtù e fortuna. In: MACHADO, Nivaldo et al. (Org.). Pensar o Direito. Rio do Sul: Editora UNIDAVI, 2011. p. 107-127.

DI PIETRO, Maria Sylvia Zanella. O princípio da supremacia do interesse público: sobrevivência diante dos ideais do neoliberalismo. In: DI PIETRO, Maria Sylvia Zanella; RIBEIRO, Carlos Vinícius Alves (Coord.). Supremacia do interesse público e outros temas relevantes do direito administrativo. São Paulo: Atlas, 2010. p. 85-102.

GABARDO, Emerson. Interesse público e subsidiariedade: o Estado e a sociedade civil para além do bem e do mal. Belo Horizonte: Fórum, 2009.

GABARDO, Emerson. O princípio da supremacia do interesse público sobre o interesse privado como fundamento do Direito Administrativo Social. Revista de Investigações Constitucionais, Curitiba, vol. 4, n. 2, p. 95-130, maio/ago. 2017.

GALÁN Y GUTIÉRREZ, Eustaquio. La filosofia política de Sto. Tomás de Aquino. Madrid: Editorial Revista de Derecho Privado, 1945. 
GROSSI, Paolo. Mitologias jurídicas da Modernidade. Tradução de Arno Dal Ri Júnior. Florianópolis: Fundação Boiteux, 2004.

HACHEM, Daniel Wunder. Princípio constitucional da supremacia do interesse público. Belo Horizonte: Fórum, 2011.

HAEBERLIN, Mártin Perius. Crítica da razão do Estado: uma (re)formulação do conceito de interesse público e a correlata construção de um Estado meritocrático de direito. 2014. 454 f. Tese (Doutorado de Direito) - Faculdade de Direito da Pontifícia Universidade Católica do Rio Grande do Sul, Porto Alegre, 2014.

HAUSER, Ester Eliana. O ideal democrático no pensamento político de Jean-Jacques Rousseau. In: WOLKMER, Antonio Carlos (Org.). Introdução à história do pensamento político. Rio de Janeiro: Renovar, 2003. p. 165-181.

HOBBES, Thomas. Leviatã ou matéria, forma e poder de um Estado eclesiástico e civil. Tradução de João Paulo Monteiro e Maria Beatriz Nizza da Silva. 2. ed. São Paulo: Martins Fontes, 2008.

HOUTART, François. Dos bens comuns ao "bem comum da humanidade”. Bruxelas: Rosa Luxemburg Foundation Brussels Office, 2011. Disponível em: <http://www.reformaagrariaemdados. org.br/sites/default/files/Dos\%20bens\%20comuns\%20ao\%20Bem\%20Comum\%20da\%20Humanidade\%20-\%20Fran\%C3\%A7ois\%20Houtart\%202011.pdf >. Acesso em 21 jan. 2018.

JAEGER, Werner. Paidéia: a formação do homem grego. Tradução de Artur M. Parreira. São Paulo: Martins Fontes, 2011.

LIXA, Ivone Morcilo. O sentido da política em Platão e Aristóteles. In: WOLKMER, Antonio Carlos (Org.). Introdução à história do pensamento político. Rio de Janeiro: Renovar, 2003. p. 11-37.

LUPI, André Lipp Pinto Basto. Uma abordagem contextualizada da teoria política de Thomas Hobbes. In: WOLKMER, Antonio Carlos (Org.). Introdução à história do pensamento político. Rio de Janeiro: Renovar, 2003. p. 93-134.

MAQUIAVEL, Nicolau. O Príncipe. Tradução de Maria Júlia Goldwasser. 3. ed. 2. tir. São Paulo: Martins Fontes, 2008.

MARTEL, Letícia de Campos Velho. O tempo e a política no pensamento de Maquiavel. In: WOLKMER, Antonio Carlos (Org.). Introdução à história do pensamento político. Rio de Janeiro: Renovar, 2003. p. 67-92.

MEZZAROBA, Orides; SILVEIRA, Vladmir Oliveira da. The principle of the dignity of human person: $A$ reading of the effectiveness of citizenship and human rights through the challenges put forward by globalization. Revista de Investigações Constitucionais, Curitiba, vol. 5, n. 1, p. 273-293, jan./abr. 2018.

MEZZAROBA, Orides; STRAPAZZON, Carlos Luiz. Direitos fundamentais e a dogmática do bem comum constitucional. Revista Sequência: Estudos Jurídicos e Políticos, Florianópolis, v. 33, n. 
64, p. 335-372, jul. 2012. Disponível em: <https://periodicos.ufsc.br/index.php/sequencia/article/ view/2177-7055.2012v33n64p335/22475>. Acesso em 21 jan. 2018.

NEQUETE, Eunice Ferreira. Fundamentos históricos do princípio da supremacia do interesse público. 2005. 238 f. Dissertação (Mestrado em Direito) - Faculdade de Direito da Universidade Federal do Rio Grande do Sul, Porto Alegre, 2005.

NUNES, Diego. Entre "O Príncipe" e a "Razão de Estado": apontamentos sobre a arte de governar entre as obras de Maquiavel e Botero. Revista Discente do Curso de Pós-Graduação em Direito da UFSC, Florianópolis, ano 1, n. 1, p. 126-145, jul./dez. 2008.

PATO, João; SCHMIDT, Luísa; GONÇALVES, Maria Eduarda (Org.). Bem comum: público e/ou privado. Lisboa: ICS (Imprensa de Ciências Sociais), 2013. Disponível em: <http://repositorio.ul.pt/ bitstream/10451/22896/1/ICS JPato LSchmidt_LEN.pdf>. Acesso em 21 jan. 2018.

PEREIRA, Américo. Da ontologia da "polis" em Platão. Covilhã: LusoSofia - Biblioteca Online de Filosofia e Cultura, p. 03-102, 2011. Disponível em: < http://pt.scribd.com/doc/56971910/Pereira-Americo-Ontologia-Da-Polis-Em-Platao>. Acesso em: 17 jan. 2018.

PINTO, Maurício Morena. A noção de vontade geral e seu papel no pensamento político de Jean-Jacques Rousseau. Cadernos de Ética e Filosofia Política do Programa de Pós-Graduação do Departamento de Filosofía da USP, São Paulo, n. 7, p. 83-97, 2. sem. 2005.

PINZANI, Alessandro. Os demônios e as facções: Kant e Madison sobre paixões e instituições. Crítica: Revista de Filosofia da Universidade Estadual de Londrina, v. 11, n. 33, p. 131-152, 2006.

PLATÃO. A República. Tradução de Edson Bini. 2. ed. São Paulo: EDIPRO, 2012.

RODRÍGUEZ-ARANA MUÑOZ, Jaime. El Derecho Administrativo ante la crisis (El Derecho Administrativo Social). A\&C - Revista de Direito Administrativo \& Constitucional, Belo Horizonte, ano 15, n. 60, p. 13-37, abr./jun. 2015.

ROULAND, Norbert. Nos confins dos Direito: antropologia jurídica da Modernidade. Tradução de Maria Ermantina de Almeida Prado Galvão. São Paulo: Martins Fontes, 2003.

ROUSSEAU, Jean-Jacques. O contrato social ou princípios de Direito Público. Tradução de Antonio de Pádua Danesi. 3. ed. 3. tir. São Paulo: Martins Fontes, 1999.

SALGADO, Eneida Desiree. Essay on the constitutional promises of democracy and republic. Revista de Investigações Constitucionais, Curitiba, vol. 4, n. 3. p. 85-100, set./dez. 2017.

SARMENTO, Daniel. Interesses públicos vs. Interesses privados na perspectiva da teoria e da fiIosofia constitucional. In: SARMENTO, Daniel. Interesses públicos versus interesses privados: desconstruindo o princípio da supremacia do interesse público. Rio de Janeiro: Lumen Juris, 2005, p. 23-116.

SEWAYBRICKER, Luciano Espósito. A felicidade na sociedade contemporânea: contraste entre diferentes perspectivas filosóficas e a Modernidade líquida. 2012. 159 f. Dissertação (Mestrado em Psicologia) - Instituto de Psicologia da Universidade de São Paulo, São Paulo, 2012. 
SKINNER, Quentin. As fundações do pensamento político moderno. Tradução de Renato Janine Ribeiro e Laura Teixeira Motta. 1. reimp. São Paulo: Companhia das Letras, 1999.

SZLEZÁK, Thomas Alexander. Platão e os pitagóricos. Tradução de Fernando Augusto da Rocha Rodrigues. Archai: Revista de Estudos sobre as Origens do Pensamento Ocidental. Brasília, n. 6, p. 121-132, 2011.

TEIXEIRA, Evilázio. A educação do Homem segundo Platão. São Paulo: Paulus, 1999.

TOMÁS DE AQUINO, Santo. Suma teológica. t. VI. Madrid: B.A.C., 1956.

WHITE, Nicholas. Breve história da felicidade. Tradução de Luis Carlos Borges. São Paulo: Loyola, 2009.

WOLKMER, Antonio Carlos. O pensamento político medieval: Santo Agostinho e Santo Tomás de Aquino. In: WOLKMER, Antonio Carlos. Introdução à história do pensamento político. Rio de Janeiro: Renovar, 2003. p. 39-66. 